\title{
コアを用いた高速応答・高精度電流センサ
}

\author{
正 員 園 田 敏 勝 (九州工大) \\ 正員上田 隆三（九州工大）
}

\section{High Response and High Accuracy Current Sensor Constituted by Using Magnetic Core}

Toshikatsu Sonoda, Member, Ryuzo Ueda, Member (Kyushu Institute of Technology)

\begin{abstract}
Vector control in induction motor drive system gives a theoretical foundation for realizing high accurate torque control. However, the control accuracy in practice depends on the performances of voltage and current sensors used for the purpose. Particularly, the current sensor is required to satisfy the following: (i) It is non-contacting type; (ii) The detectable frequency range covers from $D C$ to the one beyond over the inverter chopping frequency ; (iii) The current range over from $\mathrm{mA}$ to several $10 \mathrm{~A}$ has to be covered with the accuracy of $0.1 \%$ in FS (Full Scale); (iv) The same detection characteristics is easily obtainable for the application to each phase in three phases; (v) The effect of the environmental temperature variation on the detection characteristics is small ; (vi) The sensor is little affected by the external magnetic noise and surge voltage.

This paper presents a current sensor which has a possibility of satisfying almost all the above items by using two magnetic cores.
\end{abstract}

キーワード：ベクトル制御，電圧・電流センサ，検出精度，応答性，褰磁界，対称性

\section{1.まえがき}

インバータ駆動誘導機におけるベクトル制御は，ト ルクの高精度制御を実現する理論的な基礎を与え,パ ワーデバイスの進歩に伴い，現在実用期に入っている といえる(1) (3)。しかしながら, 実際の制御精度は用 いる電圧・電流センサの性能によって定まるといって も過言ではない。ここで電流センサに着目すると, 例 えば次の条件を满たすものが要求される。

(1) 非接触形であること。

（2）直流からインバータのチョッピング周波数 (数 $\mathrm{kHz} \sim 10 \mathrm{kHz}$ 程度) に十分追従する周波数応答 性を有すること。

（3）通常使用する誘導機を考え， mA オーダから 数 $10 \mathrm{~A}$ (4 桁程度) の範囲をカバーし, $0.1 \%$ FSの 精度を有すること。

（4）三相に用いるため同一の検出特性を有するも のが容易に得られること。
（5）温度依存性が小さいこと。

（6）外乱磁気雑音, サージ電圧の影響を受けにく いこと。

コアを用いた電流センサとして筆者らはコアの動作 磁界レベルが等価的に零になるように制御して検出す る, いわゆる零磁界形の電流センサについて検討して きた。その検出特性は応答性を除き上記の条件を十分 に満足するものであったた ${ }^{(4)(5)}$ 。

本論文ては，応答性の改善と高精度化を実現すべく 直流パイアス方式 ${ }^{(6)(7)}$ 導入した零磁界形の電流セン サについて倹討する。直流バイアス方式とは, あらか じめトロイダルコアニ個に大きさが等しく逆極性の直 流バイアス磁界を印加し，これを各コアの動作磁界レ ベルとする。次に，それぞれの動作磁界レベルが被検 出電流によってともに同方向にシフトするように巻線 を施すと, 各動作点に括ける增分透磁率の変化は互い に逆になる。この両者の変化分を高周波の補助励磁に 対する探りコイル電圧の変化としてとらえることによ 
り，両コアの磁化状態を知る方式である。この方式の 特徵はコアの動作磁界レベルを, いわゆる回転磁化あ るいは飽和漸近範团 ${ }^{(8)}$ に設定することにより，メジャ ーループでは困難であった高周波励磁が可能となり， 応答性の改善が期待できる。また，雲磁界とは閉ルー プ化することにより，先のシフト分を相殺するように 両コアを逆励磁し，その電流加ら被検出電流を知るこ とを意味する。このようにするとコア自身の磁気特性 が直接表に出ない形で検出特性が定まり, 高精度化を 実現できる。実際コバルト基のアモルファスコアを用 い, その補助励磁周波数を $1.0 \mathrm{MHz}$ とした場合, 振 幅比で $-0.1 \mathrm{~dB}$, 位相差については $8^{\circ}$ の遅れを許せ ば DC から $20 \mathrm{kHz}$ の範囲をカバーし，1 A FSに対 して精度 $0.5 \%$ 程度のセンサを構成することができ た。また，微小電流検出時にしばしば見受けられる一 種のヒステリシス現象 ${ }^{(9)} は$ は, バイアスレベルを梁くす ることにより $100 \mu \mathrm{A}$ 以下の電流に対してもな扔認め られなかった。ところが, 磁化状態を検出するのに二 磁心を用いているため, 両コアの温度変化に基づいて 生じる動作磁界の対称性の崩れは, 室温から $100^{\circ} \mathrm{C} の$ 上昇に対し $6 \%$ 近くに達することから, 温度特性の改 善に対しては, 用いるコア材質の選択を含めて今後に 問題を残した。以上の結果, 一磁心形と二磁心形の特 徵を明確にすることができた。

\section{2. 提案する電流センサの検出原理}

一般に零磁界形の電流あるいは磁界センサを実現す るためには，コアの磁化状態を正確に知る方法を確立 する必要があった。これに対し, 著者らは二つの方法 を示した。その一つは探りコイル上から見たコアの磁 化特性が，被検出電流 $i_{1}$ による磁界によって異なる ことに着目したもの, 他の一つはコアの高角形磁化特 性を利用する方法であっだ(4)(5)。それらはいずれも補 助励磁周波数の一周期あるいは半周期後でなければ動

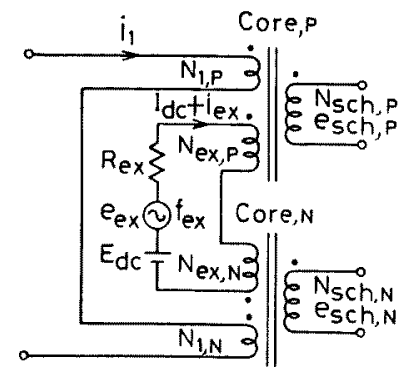

図 1 直流バイアス形電流センサの基本構成 Fig. 1. Fundamental configuration of DC. biased type current sensor.
作磁界レベルの判断ができないため,この周波数で強 出の応答性は規定された。上記二方法をコアの $B-H$ ループから見た場合, いずれも過励振という条件で励 磁しているため, 微小電流検出時のヒステリシス現象 は問題にならなかったが，励磁周波数はコアの発熱， あるいは励磁電源が大形になるため高くとれなかっ た。これに対して図 1 は二個のトロイダルコア (Core, p, Core, N)を用いた直流バイアス形電流センサ の基本構成（なおこれ自身で開ループ形の電流セン サになる。）を示したものて，その動作磁界レベルを 鉄椇の小さくなる回転磁化あるいは飽和漸近範囲に設 定することにより，高周波励磁を可能とし，応答性を 格段に改善することを目指している。図 2 はその動作 原理を示したものである。あらかじめ両コアに対称な 逆極性の直流バイアス磁界 $\pm H_{\mathrm{dc}}$ を $I_{\mathrm{dc}}$ でちえて動作 磁界レベルを定める。次にその動作レベルが $i_{1} に よ$ って生じる磁界 $H_{1}\left(\propto i_{1}\right)$ に対しては同相に, 磁化状 態を知るための補助励磁磁界 $h_{\text {ex }}$ (補助励磁電流 $i_{e x}$, 周波数 $f_{e x}$ で与える) に対しては互いに逆相になるよ うに巻線 $N_{e x, \mathrm{P}}, N_{\text {ex,N }}$ をそれぞれ施す。そうすると,

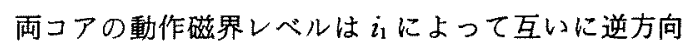
にシフトすることになり，各コアの動作点における $h_{e x}$ に対する増分透磁率 $\mu_{\Delta}=\Delta B / \Delta H$ は互いに逆方 向に変化する。この両者の変化分を $h_{\text {ex }}$ に対する探り
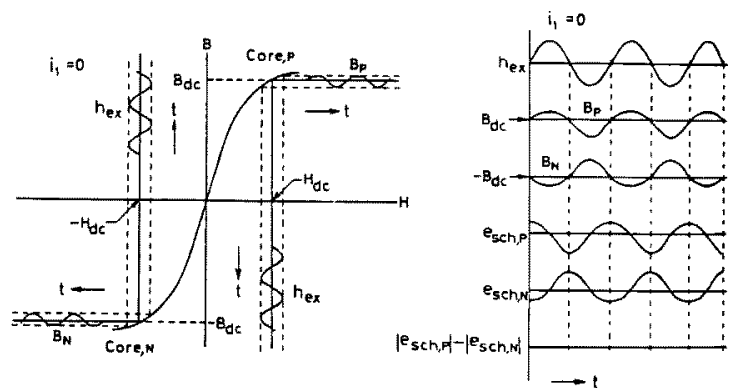

(a) $i_{1}=0$ の場合

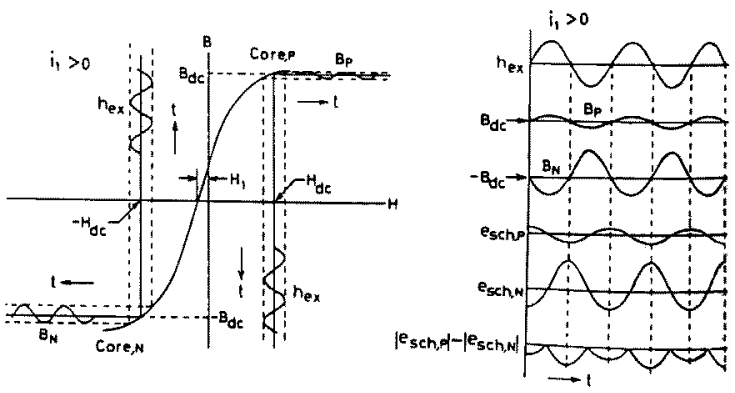

(b) $i_{1}>0$ の場合

図 2 検出動作

Fig. 2. Detection principle. 


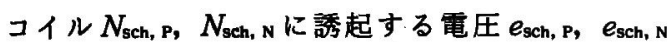
の変化として捕らえれば,これからコアの磁化状態を 知ることができる。

$i_{1}$ と $e_{\text {sch }}$ との関係を調べるにあたり次の仮定を置く。

（1）各コアは同一の飽和特性を有し，ヒステリシ スはないものとする。なお簡単のため, コア内の渦電 流は存在しないものとする。

（2） $i_{e x}$ から見た場合， $i_{1}$ は直流とみなせる。

（3）直流バイアス磁界と比較し $H_{e x, m}, H_{1}$ はと もに十分小さいとする。

$H_{\mathrm{dc}} \gg H_{e x, m}, H_{1}$

（4）動作磁界レベルを十分深くとることにより補 助励磁磁界は正弦波で与えられるものとする。

$h_{e x}=H_{e x, m} \sin \omega_{e x} t$

各コアの動作磁界 $H_{\mathrm{P}}, H_{\mathrm{N}}$ は (3) 式で与えられるが

$$
\left.\begin{array}{l}
H_{\mathrm{P}}=H_{1}+H_{\mathrm{dc}} \\
H_{\mathrm{N}}=H_{1}-H_{\mathrm{dc}}
\end{array}\right\}
$$

$i_{1}=0$ すなわち $H_{1}=0$ の場合には，図 2 (a) に示す動 作から (4)式に示すように各 $e_{\text {sch }}$ の大きさは等しく 逆極性の電圧になる。

$e_{\mathrm{sch}, \mathrm{P}, \mathrm{o}}=-N_{\mathrm{sch}, \mathrm{P}} d \phi_{0} / d t$

$$
\begin{aligned}
& \fallingdotseq-A_{1} \mu_{\Delta, 0} \cos \omega_{\text {ex }} t \\
& =-e_{\text {sch }, \mathrm{N}, 0} \cdots \cdots \cdots \cdots . . . . .
\end{aligned}
$$

ここで

$$
\mu_{\Delta, \mathrm{P}, 0}=\mu_{\Delta, \mathrm{N}, 0}=\mu_{\Delta, 0}
$$

$A_{1}=N_{\text {sch }} S \mu_{0} \omega_{e x} H_{\text {ex }, m}$

$e_{\text {sch, } 0}: i_{1}=0$ 時における各探りコイルに誘起 する電圧の瞬時值, $N_{\mathrm{sch}}$ : 各コアに施した探 りコイルの巻回数, $\phi_{0}: i_{1}=0$ 時の $h_{e x} に よ$ って生じた各探りコイルと鎖交する磁束数, $S:$ コアの等価断面積, $\mu_{\Delta, 0}: i_{1}=0$ の場合の 動作磁界レペルにおける $h_{\text {ex }}$ に対する增分透 磁率, $H_{e x, m}: h_{e x}$ の最大値, $\omega_{e x}: h_{e x}$ の角 周波数,

$i_{1}>0$ の場合には, 図 2 ( b ) に示すように各動作点 がともに $H_{1}$ だけシフトした点が新しい動作点にな る。この点における増分透磁率をそれぞれ $\mu_{\Delta}$ とし, シフトに伴う $\mu_{\Delta}$ の変化分を $\Delta \mu_{\Delta}$ とするとCore,p $H_{\mathrm{dc}}$ より深くバイアスされ，逆にCore, で, 次式が得られる。

$$
\left.\begin{array}{ll}
\mu_{\Delta, \mathrm{P}}=\mu_{\Delta, 0}-\Delta \mu_{\Delta, \mathrm{P}} & \left(\mu_{\Delta, \mathrm{P}}<\mu_{\Delta, 0}\right) \\
\mu_{\Delta, \mathrm{N}}=\mu_{\Delta, 0}+\Delta \mu_{\Delta, \mathrm{N}} & \left(\mu_{\Delta, \mathrm{N}}>\mu_{\Delta, 0}\right)
\end{array}\right\}
$$

従って, この場合の各探りコイル電圧は, $(8)$ 式とな り, 両者の和は $(9)$ 式で与えられる。

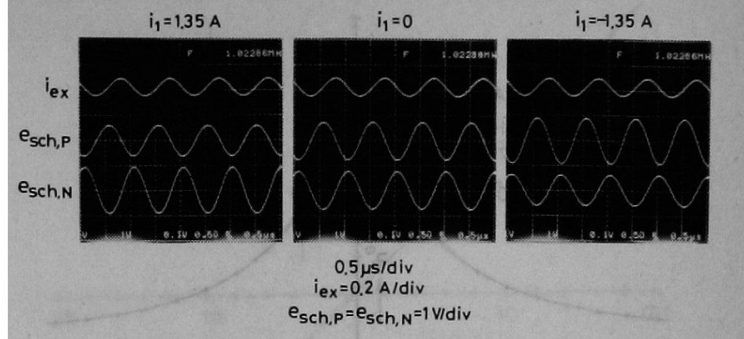

図 3 検出動作波形

Fig. 3. Wave-forms of $i_{e x}$ and $e_{\text {sch. }}$

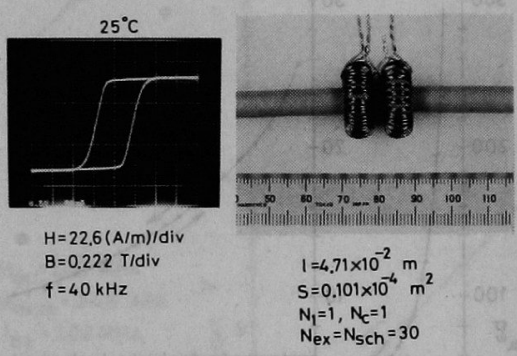

図 $4 B-H$ ループおよびセンサ外観 Fig. 4. $B-H$ loop of the core and external shape of the sensor.

$$
\begin{aligned}
& e_{\mathrm{sch}, \mathrm{P}}=A_{1} \mu_{\Delta, \mathrm{P}} \cos \omega_{e x} t \\
& e_{\text {sch, }}=-A_{1} \mu_{\Delta, \mathrm{N}} \cos \omega_{\text {ext }} t \\
& \Delta e_{\text {sch }}=e_{\text {sch, } \mathrm{P}}+e_{\text {sch, } \mathrm{N}} \\
& =-\left(\Delta \mu_{\Delta, \mathrm{p}}+\Delta \mu_{\Delta, \mathrm{N}}\right) A_{1} \cos \omega_{e x} t \cdots
\end{aligned}
$$

同様に $i_{1}<0$ の場合には $(9)$ 式とは逆位相の $\Delta e_{\mathrm{sch}}$ と なることから, 各探りコイルの電圧からコアの磁化状 態を知ることができる。

図 3 は以上のことを確認するため, 図 4 に示す $B-$ $H$ ループと同じ材質のアモルファストロイダルコア $\left(l=4.71 \times 10^{-2} \mathrm{~m}, S=0.101 \times 10^{-4} \mathrm{~m}^{2}\right)$ を用いて, 写 真に示すようなセンサを試作し，これを次の条件で励 磁した場合の $e_{\mathrm{sch}}$ の波形を示したものである。ここ では動作を明確に示すため $H_{1}$ すなわち $i_{1}$ を大きく与 えている。

$$
\begin{aligned}
& N_{1}=1, N_{e x}=N_{\text {sch }}=30, H_{\mathrm{dc}}=240 \mathrm{~A} / \mathrm{m} \\
& H_{e x, m}=24.6 \mathrm{~A} / \mathrm{m}, f_{e x}=1.02 \mathrm{MHz}
\end{aligned}
$$

いま, $i_{1}=0,1.35,-1.35 \mathrm{~A}(\mathrm{rms}), \quad\left(\rightarrow H_{1}=0\right.$, $\pm 28.66 \mathrm{~A} / \mathrm{m})$ とした場合の各 $i_{1}$ に対する探りコイ 儿電圧はおおよそ $1.55,1.3 ， 1.8 \mathrm{~V}(\mathrm{p}-\mathrm{p})$ となり, これからコアの等価比透磁率 $\mu_{e q}$ を(10)式から求める と $12.7,10.7,14.8$ 程度になる。ここで $E_{\mathrm{sch}}$ は $e_{\mathrm{sch}}$ の実効值である。 

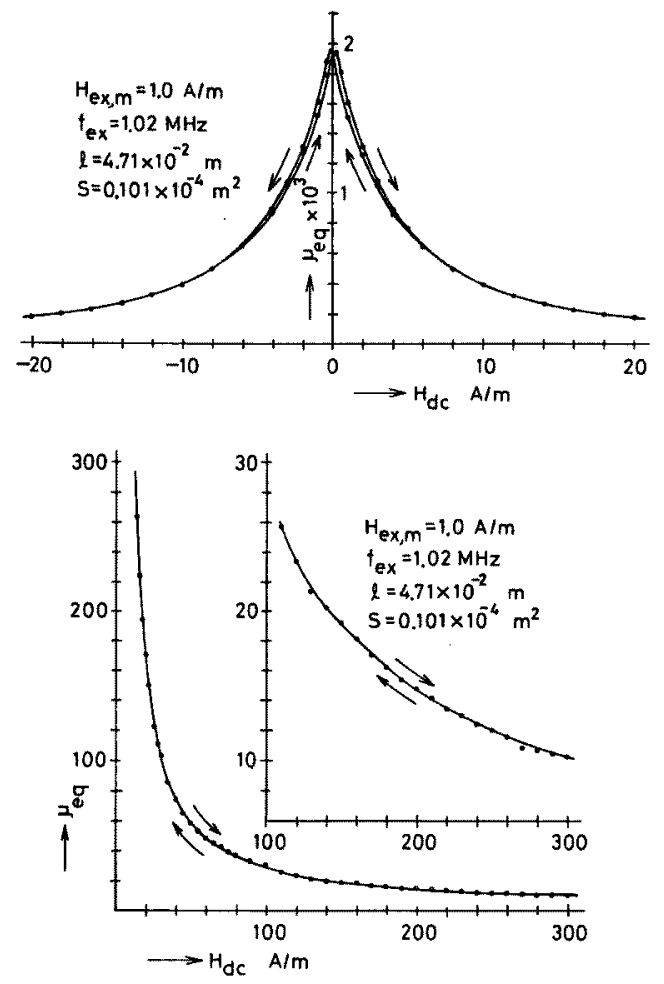

図 5 バイアス磁界に対する等価比透磁率

Fig. 5. Characteristics of $\mu_{e q}$ versus $H_{\mathrm{dc}}$.

$$
\mu_{e q}=\sqrt{2} E_{\mathrm{sch}} /\left(N_{\mathrm{sch}} \mu_{0} S \omega_{e x} H_{e x, m}\right)
$$

図 5 は $\mu_{e q}$ と $\mu_{\Delta}$ との等洒性を考慮し $H_{e x, m}=$ $1.0 \mathrm{~A} / \mathrm{m}$ と小さくした場合の $H_{\mathrm{dc}}$ に対する $\mu_{e q}$ を求 めたものである。これを図 3 と同じ動作磁界レベル $(240,211.34,268.66 \mathrm{~A} / \mathrm{m})$ における値と比較する とそれぞれ $12.4,10.9 ， 14$ となり，ほとんど同じ值 になっている。すなわち，hexに対する探りコイル電 王の実効值は $H_{e x, m}$ の大きさに比例しており，この ように $H_{\mathrm{dc}}$ の大きい範囲では $H_{e x, m}$ の変化に対する $\mu_{e q}$ の変化は小さく，大きな差にはならなかった。こ のことは，本来探りコイル電圧は，(4)式に基つ゚いて 議論しなければならないが，このように も大差ないことを示しており，e $e_{\mathrm{sch}}$ は正弦波に近い波 形であったと言える。なお，この動作磁界における $\mu_{e q}$ は次に示すコアゲイン，すなわち開ループ時の検 出感度を左右することになる。

実際の検出動作は $e_{\mathrm{sch}, \mathrm{P}}$ と $e_{\mathrm{sch}, \mathrm{N}}$ の振幅差からコア の磁化状態を知るので，これを考慮し， $H_{\mathrm{dc}}=$ $240 \mathrm{~A} / \mathrm{m}$ における一次巻線に対する平均的な等価コ アゲン $K_{\text {core, N1 }}$ を(11)式で定義して求めると次のよう

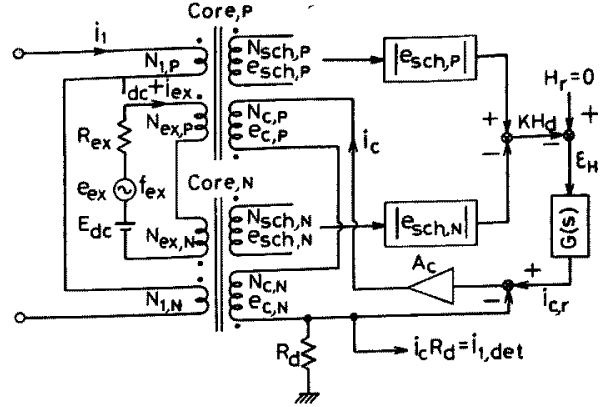

図 6 塞磁界を導人した直流バイアス形 電流センサ

Fig. 6. Block diagram of the zero magnetic field DC-biased type current sensor.

になる。

$$
\begin{aligned}
K_{\text {core }, \mathrm{N} 1} & \equiv\left\{\left(\Delta \mu_{\Delta, \mathrm{N}} / \Delta i_{1}\right)+\left(\Delta \mu_{\Delta, \mathrm{P}} / \Delta i_{1}\right)\right\} / 2 \\
& =1.52 \ldots \ldots \ldots \ldots \ldots \ldots \ldots \ldots \ldots \ldots \ldots \ldots \ldots \ldots \ldots \ldots \ldots
\end{aligned}
$$

\section{3. センサの回路構成例}

図 6 は第 2 章で示した磁界レベル検出法を用いて雺 磁界形の電流センサとして構成した場合の一回路例で

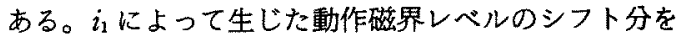
各 $e_{\text {sch }}$ の絶対值の差より求め, このシフト分が $i_{1}=0$ 時の状態になるように制御巻線 $N_{c}$ に制御電流 $i_{c}$ を流 す，すなわち逆励磁して，この $i_{c}$ 加ら $i_{1}$ を検出する ものである。ここで， $e_{\mathrm{sch}}$ の絶対值を用いたのは次の 理由による。コアの磁化状態を知るのに(9)式を用い るとすれば， $\Delta e_{\text {sch }}$ を $i_{e x} に$ 対して同期整流する必要 がある。またこの方法からは，コアの瞬時磁化状態を 知るのは困難である。ところが絶対值の差を用いれ ば，図 2 (b)に示すように，各 esch がゼロクロスす る瞬間を除くと，常にコアの磁化状態を知ることがて きることになる。これより零磁界を実現すれば，瞬時 応答形の電流センサを奏現できる可能性がある。しか し，eschがゼロクロスする瞬間の問題は別に解決しな ければならない。

図6より

$$
\begin{aligned}
K H_{d}= & \left(\left|e_{\text {sch, } \mathrm{P}}\right|-\left|e_{\text {sch, } \mathrm{N}}\right|\right) G_{\mathrm{Rec}}(s) \\
= & A_{1}\left\{\mu_{\Delta, \mathrm{o}}-\Delta \mu_{\Delta, \mathrm{P}}-\left(\mu_{\Delta, 0}\right.\right. \\
& \left.\left.+\Delta \mu_{\Delta, \mathrm{N}}\right)\right\} G_{\mathrm{Rec}}(s) \\
= & -A_{1}\left(K_{\text {core, } \mathrm{N} 1} \Delta i_{1}+K_{\text {core, } \left.\mathrm{c} \Delta i_{c}\right) G_{\mathrm{Rec}}(s)}\right.
\end{aligned}
$$

ここに, $G_{\mathrm{Rec}}(s)$ は各コアの磁化状態を平均値として とらえるために挿入した一次道れで, 各 $e_{\text {sch }}$ のゼロ クロス点における補償も兼ねている。なお，その時定 


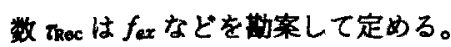

$$
G_{\mathrm{ReC}}(s)=1 /\left(1+s \mathrm{~s}_{\mathrm{Rec}}\right) \text {. }
$$

また Koore, c は(11)式と同様に $N_{c}$ に対する平均的な 等価コアグインである。

$$
\begin{aligned}
K_{\text {core, } c} \equiv & \left\{\left(\Delta \mu_{, \mathrm{N}} / \Delta i_{c}\right)\right. \\
& \left.+\left(\Delta \mu_{\Delta, \mathrm{p}} / \Delta i_{c}\right)\right\} / 2
\end{aligned}
$$

$i_{c}$ の目楎值 $i_{c, r}$ は

$$
i_{c, r}=\varepsilon_{M} G(s)=K H_{d} G(s)
$$

ここに， $\varepsilon_{H}$ はコアの磁界レベルの目標値 $H_{r}$ と $K H_{d}$ との偏差である。ここで $H_{r}=0$ は各コアの動作磁界 レベルの目標值が $\pm H_{\mathrm{dc}}$ であることを意味する。 $N_{c}$ につながる電流アンプ $A_{c}$ のゲインが十分大きいとす ると，(16)，(17)式が得られる。

$$
\begin{aligned}
& i_{c, r}=i_{c} R_{d} \\
& i_{c}=-A_{1}\left(K_{\text {core, N1 }} \Delta i_{1}+K_{\text {core, } c} \Delta i_{c}\right) \\
& \times G_{\mathrm{Rec}}(s) G(s) / R_{d}
\end{aligned}
$$

ここで，G(s)のゲインが十分大きいとすると，(18) 式が得られる。

$$
\begin{aligned}
& \Delta i_{c}=-K_{R} \Delta i_{1} \ldots \ldots . . \\
& K_{R}=K_{\text {core, N1 }} / K_{\text {core, } c}
\end{aligned}
$$

ここて，常に零磁状態が保たれる，すなわち $\Delta i_{1}$ に基 づくシフト分は饅時に $i_{c}$ で逆励磁されるとすれば， 各コアの動作磁界は $\pm H_{\mathrm{dc}}$ となり $K_{R}$ の值が一意に定 ま $, \Delta i_{1} \rightarrow i_{1}, \Delta i_{c} \rightarrow i_{c}$ と置ける。従って, $i_{1}$ 泣 (20)式として検出されることになる。

$$
i_{1, \text { det }}=i_{c} R_{d}=-K_{R} R_{d} i_{1}
$$

ここてコアの対称性は得られているものとして, セン サ回路を構成する電子回路のオフセットやドリフトの 影济（ここでは簡単の為両者を合わせた影濖を $f\left(D_{0}\right)$ と表現する。）について考えてみる。まず Idcを元 る回路の $f\left(D_{0, l d c}\right)$ だが，これはコアの対称性により 相殺され問題にならない。 $N_{c}$ につながる電流アンプ の $f\left(D_{0, N c}\right)$ は， $G(s)$ のゲインに依存するが, 基本的 にこれも問題にならないと言える。結果的に問題にな るのは(12)式の $K H_{d}$ を得るために構成する回路の $f\left(D_{0, k H d}\right)$ であり,これは等価的に $H_{r} \neq 0 つ ま り \varepsilon_{H}$ の存在として現れることになる。しかしながら，第 5 章で検討するコアの非対称性に基づく誤差と比較する と電子回路自身の $f\left(D_{0}\right)$ はほとんど問題にならない。

\section{4. 検出特性}

図 7 は独立に静電シールドされた二本の重線を平行 な状站で両センサコアに䔬通させ，すなわち $N_{1}=N_{c}$ $=1, K_{R}=1.00$ を得, 励磁条件を図 3 の場合と等し くした場合の直流検出特性を示したものである。な
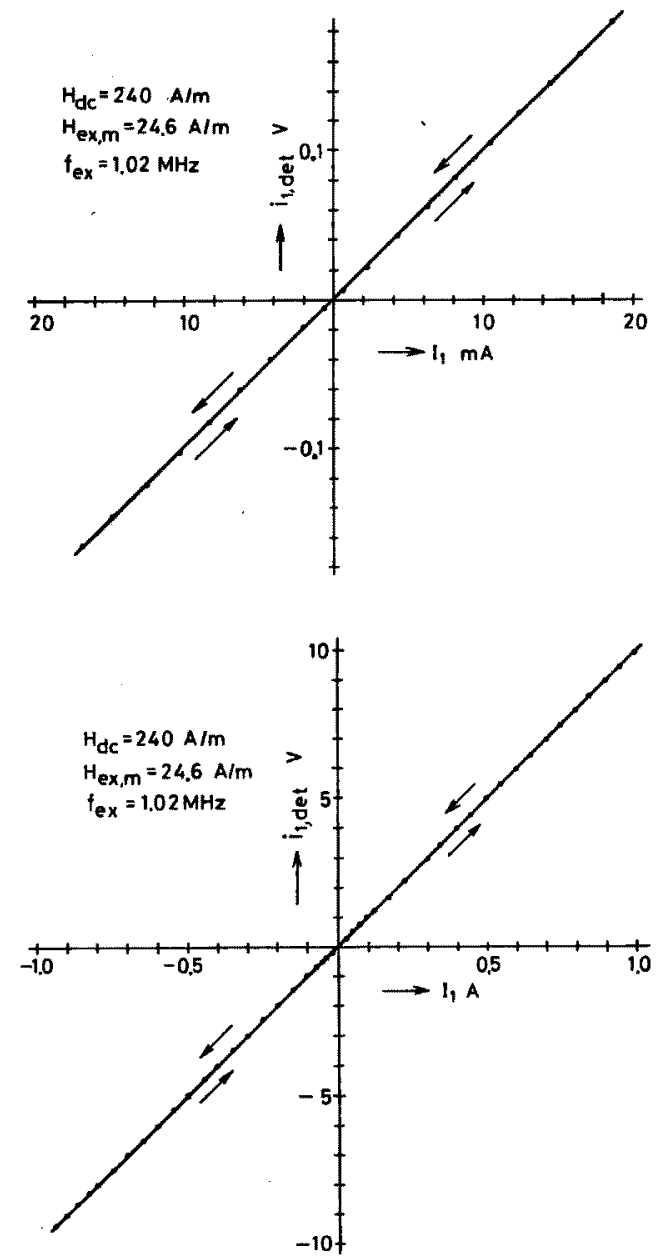

(a) 直線性

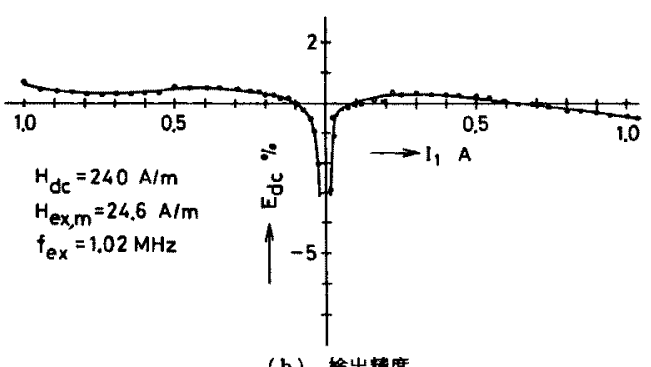

（b）梙出棈度

図 7 直流検出特性

Fig. 7. DC current detection characteristics.

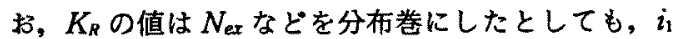
が交流の場合には, 直流と比較するとわずかであるが コアを貫通する $N_{1}, N_{c}$ の位置に依存することがあ る。このことはトロイダルコアが必ずしも至るところ 

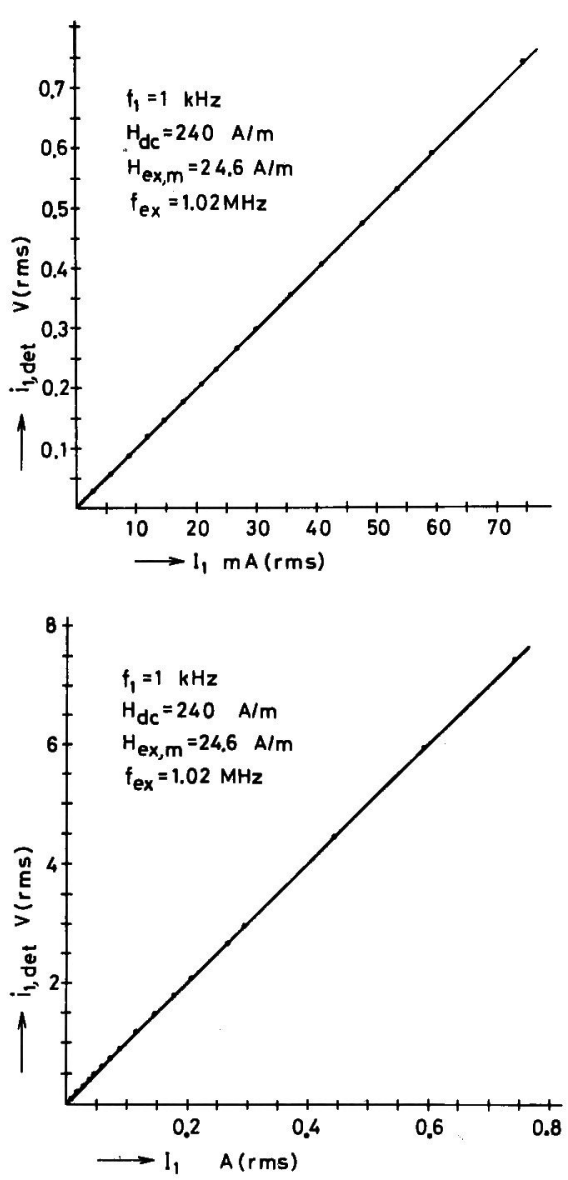

(a) 直線性

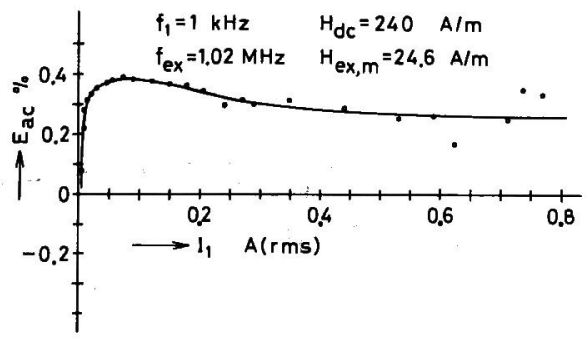

(b) 検出精度

図 8 交流検出特性

Fig. 8. AC current detection characteristics.

一様でないことを意味する(10)。また当然であるが， 検出電流を拡大するため $N_{c}$ を 2 以上にすると，動作 磁界レベル（ $\mu_{\Delta}$ の大きさ）にも依存するが, $N_{c}$ の巻 数と $K_{R}$ との比例性が，厳密には成立しなくなる。 直流検出誤差 $E_{\mathrm{dc}}$ は $R_{d}$ を $1.0 \Omega$ に等価換算して,

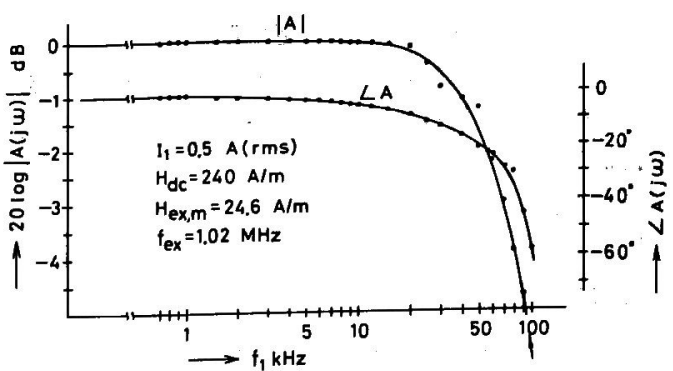

図 9 周波数特性

Fig. 9. Frequency characteristics.

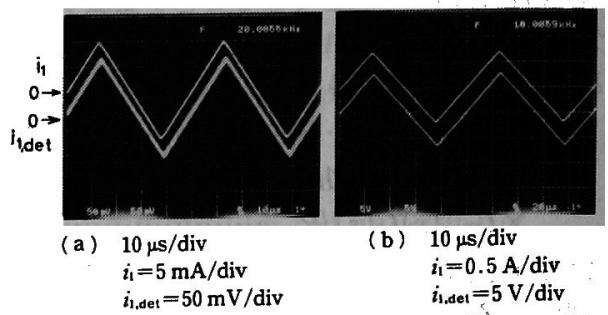

図 10 動特性

Fig. 10. Dynamic response in time domain.

(21)式より求めた。

$$
E_{\mathrm{dc}}=\left(1-i_{1, \text { det }} / i_{1}\right) \times 100
$$

これより, $\mathrm{mA}$ オーダから $1 \mathrm{~A}$ の範囲を $0.5 \%$ 程度の 精度で検出しており, 微小電流検出時のヒステリシス は $H_{\mathrm{dc}}$ を $240 \mathrm{~A} / \mathrm{m}$ と十分深くバイアスしたために認 められなかった。なお，検出精度が良くないのは次の 理由による。つまり本論文では，応答性に主眼を置い たため $G(s)$ を比例ゲインのみとし，その值は系の安 定性を考慮し $48.3 \mathrm{~dB}$ と小さ目に設定したためであ る。逆に応答性を問題にしなければ， $G(s)$ の比例ゲ インを小さくし，これに積分要素を加えることによ り，十分な精度が得られる（1 A FSに対し 0.01\%）。 このように応答性と精度との間には相反する関係が存 在し, 具体的な $G(s)$ は被測定電流を勘案して定める ことになる。

図 8 は正弦波 $1 \mathrm{kHz}$ の振幅変化に対する特性を示 す。この場合も直流検出の場合とほぼ同程度の精度て あった。また図 9 は $I_{1}=0.5 \mathrm{~A}$ (rms) で $f_{1}=100 \mathrm{~Hz}$ の検出電圧を $0 \mathrm{~dB}$ として基準化し， $f_{1}$ の周波数を変 化した場合の検出特性 $A(s)$ のボード線図である。”振 幅比でー0.1 dB, 位相差で $8^{\circ}$ の遅れを許せば DCか ら $20 \mathrm{kHz}$ をカバーしており，-3 dBでは $70 \mathrm{kHz}$ でをカバーできることを示している。図 10 は動特性 を示したもので， $f_{1}=20 \mathrm{kHz}$ (三角波) とし(a)図は 


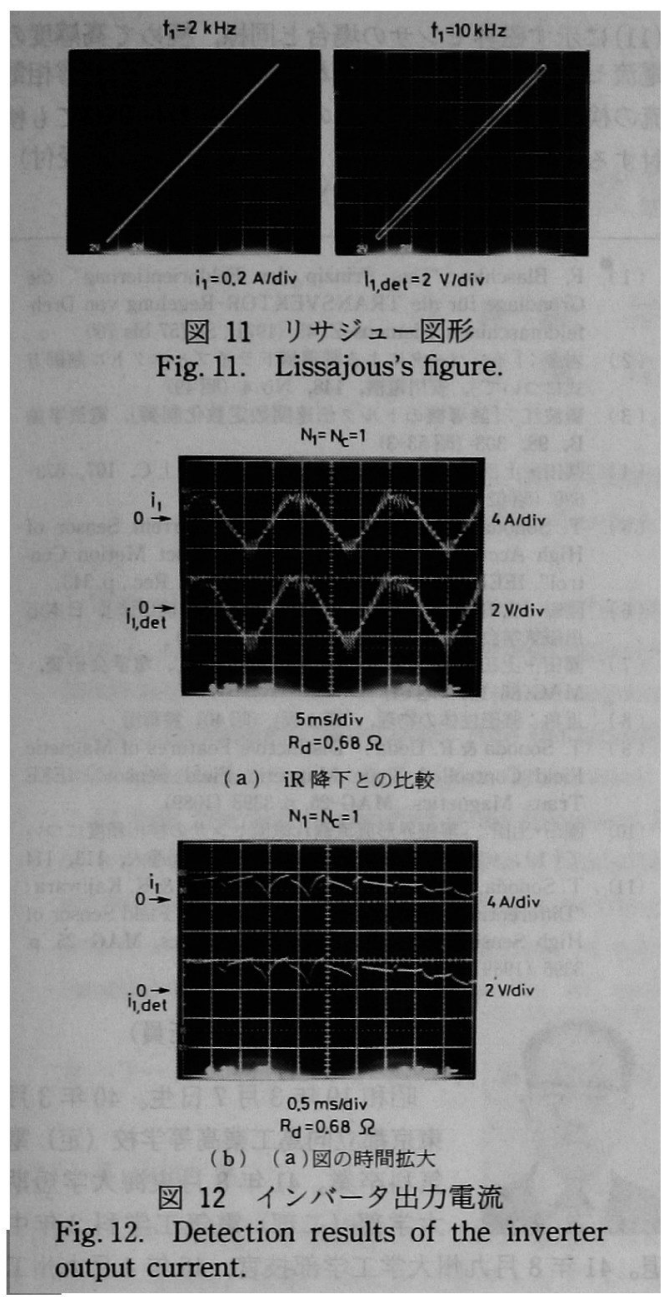

$i_{1}=5 \mathrm{~mA} / \mathrm{div}$, ( $\mathrm{b}$ )図は $i_{1}=0.5 \mathrm{~A} / \mathrm{div}$ の場合であ

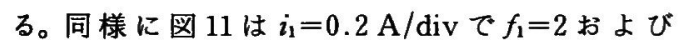
$10 \mathrm{kH}$ に対するリサジュー図形を示したもので，これ からも動的な線形性に問題のないことがわかる。なお これら検出波形と(13)式の時定数 $\tau_{\mathrm{Rec}}(=1.22 \times$ $\left.10^{-6}\right)$ との関係について考えると, $2 f_{\text {ex }}$ に対する (13) 式の大きさは 0.0638 になることから, 当然 $f_{e x}$ 成分 が検出信号に現れるはずである。図 10（a ）にはその 影響が認められるものの, 十分に除去されているとし て良い。このことは， $G(s)$ おょび $A_{c}$ が単純な比例 ゲインみでなく遅れ要素を含んでいることを意味して いる。

結果的に提案するセンサは, 直流から $10 \mathrm{kHz}$ 程度 まての周波数に対し十分な特性を有すると考えてよ い。これを実際インバータ駆動される誘導機の電流検

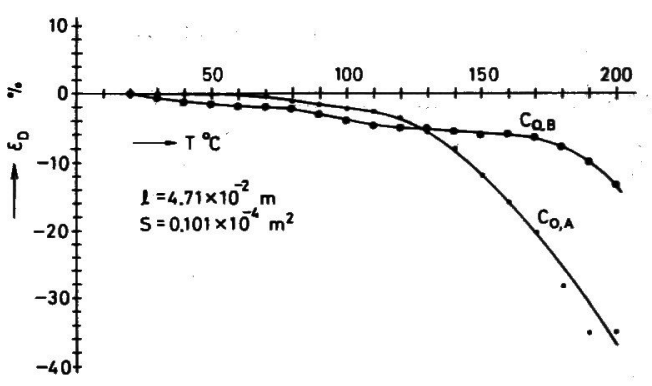

図 13 温度変化に対するコアの非対称性

Fig. 13. Temperature effect on the symmetry for two cores.

出に適用した例を図 12 に示す。(a)図の上部波形は 電流検出抵抗の $i R$ 降下を示し, 下部はセンサの検出 波形である。これの時間を拡大したのが( $(\mathrm{b})$ 図であ る。これからインバー夕電流が遅れなく検出されてい ると言えるが, よく観察すると $i_{1}$ の時間微分に基づ くと考えられる成分が若干認められる。

\section{5. コアの非対称性と検出精度}

文献 (4)，（5)，（9)に示したように一磁心で動作 磁界レベルを知り,これを零磁界として構成した電 流・磁界センサの検出精度を支配する要因は, 補助励 磁磁界に対するセンサコアの $B-H$ ループが原点対称 性を有して動作しているか否かのみであった。これは コアを過励振すれば一応満足されることから，原理的 な検出上限は存在しない, センサコアの形状や磁化特 性が直接検出特性を定めないと言う結果を得た。従つ て, 温度依存性もなくなるはずである。実際, 磁界七 ンサを例に取るとー76 $300^{\circ} \mathrm{C}$ 変化に対し $10^{-4} \% /{ }^{\circ} \mathrm{C}$ (FS) と言うように一磁心で零磁界の特徵 がよく生かされたセンサを実現できた。ところが, 本 論文で検討しているセンサは二磁心形であるため, 前 述のセンサと比較すると両コアの定常的な非対称性が 極めて大きく検出特性に現れることになる。図 13 は 実験に用いた二組のコアの非対称率を(22)式で定義し て求めた温度依存性である。ここに $E_{\mathrm{sch}}$ は $e_{\mathrm{sch}}$ の実 効值である。

$$
E_{D} \equiv \frac{E_{\mathrm{sch}, \mathrm{P}}-E_{\mathrm{sch}, \mathrm{N}}}{2\left(E_{\mathrm{sch}, \mathrm{P}}+E_{\mathrm{sch}, \mathrm{N}}\right)} \times 100
$$

$C_{0, A}$ はあらかじめ室温で対称性が得られているもの の組合せ， $C_{0,8}$ は得られていないものの組合せであ るが,ここで片方の $e_{\text {sch }}$ にある重みを付け, 常温で は等価的に対称性が得られるようにして測定してい る。 $25^{\circ} \mathrm{C}$ から $200^{\circ} \mathrm{C}$ の変化に対し $C_{0, A}$ は $37 \% \mathrm{~B}$ は $13.3 \%$ も変化している。これから, むしろ常温で対 


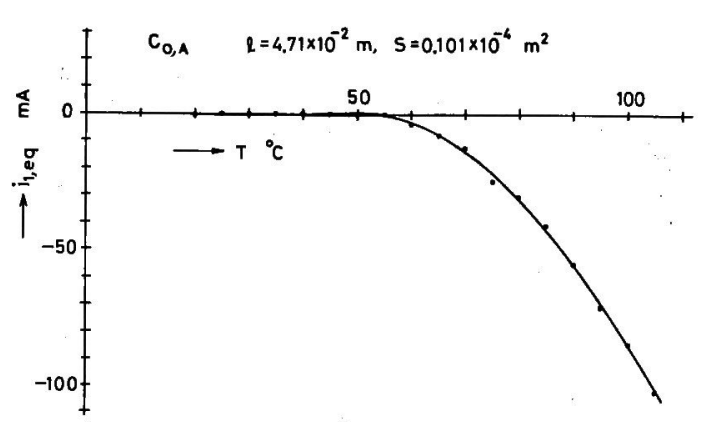

図 14 センサの温度特性

Fig. 14. Temperature characteristics.

称性の悪いほうが逆に温度変化に対しては良いと言う 結果になっている。この非対称性が実際のセンサで は, どのように影響するかを $C_{0, A}$ の組合せを用いて 調べたのが図 14 である。55ㄷまでは問題ないがこれ 以上で影響が現れ始め, 被検出電流に換算した制御電 流 $i_{1, e q}$ が余分に流れることになる。例えば， $100^{\circ} \mathrm{Cて}$ はその大きさはー $85 \mathrm{~mA}$ に相当する。この温度依存 性に対しては, 特性の良く一致したつまり， $E_{D}$ が小 さくなるコアの組合せを得ることにより解決するが, これは動作磁界レベルの検出に二磁心を用いる方式特 有の問題と言える。

\section{6.むすび}

二磁心を用いてコアの磁化状態を知る直流バイアス 法を適用した零磁界形電流センサについて検討した。 その結果, 高周波励磁を可能にしたため, 応答性に関 しては一応の改善を見ることができた。

二磁心形特有の詿差要因である，両コアの温度変化 に基づいて生じる非対称性は，温度管理を行えば解決 するがやっかいである。従って，この問題について は，用いるコア材質の選択を含めて今後検討する予定 である。

直流バイアス法は本来高い検出感度を有すが，本論 文では，応答性と安定性に着目し，動作磁界レベルを 十分に深く設定して動作させた。すなわち $\mu_{\Delta}$ の小さ いところを動作磁界レベルに設定したため，外来雑音 磁界の影響は，被検出電流の作る磁界に等価換算して 比較すると文献 ( 5 ) の場合より大きく現れ $616 \mathrm{~A} / \mathrm{m}$, $1 \mathrm{kHz}$ の雑音に対し， $0.107 \%, 10 \mathrm{kHz}$ では $0.44 \% て ゙$ あった。もちろんこの值も非対称性に依存する。ま たサージ電圧に関してはコア近傍の $N_{1}$ に対して静電 シールドを施せばよいが，その高周波に対するインピ ーダンスを考慮する必要がある。なお,コアゲインが 大きくなる範囲に動作磁界レベルを設定すれば, 文献
（11）に示す磁界センサの場合と同様，極めて高感度の 電流センサになると考えられることから, 微小零相電 流の検出，雑音磁界発生源の特定用などについても検 討する予定である。

(平成 2 年 4 月 2 日受付)

$$
\text { 文献 }
$$

(1) F. Blaschke: "Das Prinzip der Feldorientierung", die Grundlage für die TRANSVEKTOR-Regelung von Drehfeldmaschinen, Siemens-Z. 45 (1971) S. 757 bis 760

（2）岩金:「インバー夕による誘籍機ドライブとベクトル制御方 式について」, 安川電機, 148, No.4 (昭 49)

（3）難波江：「誘導機のトルク伝達関数定数化制御」, 電気学論 B, 98, 303 (昭 53-3)

（4）園田・上田：「磁界制御形電流センサ」, 同上C, 107，673680 (昭 62-7)

(5) T. Sonoda, R. Ueda \& K. Koga : “A Current Sensor of High Accuracy Fit for Precise and Exact Motion Control", IEEE IAS 1989 Ann. Meating Conf. Rec., p. 343

（6）園田・上田:「コアの碰束レべルの新しけ一模出法」, 日本応 用磁気学会学術講演概要集, $4 \mathrm{aC}-9$ (昭 61)

（7）園田・上田:「直流バイアス形電流センサ」, 電学会研资, MAG-86-157 (昭 61)

（8）近角：强磁性体の物理，(第 4 版）(昭 40) 裳華房

(9) T. Sonoda \& R. Ueda: "Distinctive Features of Magnetic Field Controlled Type Magnetic Field Sensor", IEEE Trans. Magnetics., MAG-25, p. 3393 (1989)

（10）園田・上田：「雾磁界形直流漏九電流センサの検出精度につい $\tau(1),(2)$, 昭 61 電気関係学会九州支部連大, 113,114

(11) T. Sonoda, R. Ueda, H. Ikemoto. K. Kudo \& K. Kajiwara : "Differentially DC Biased Type Magnetic Field Sensor of High Sensitivity", IEEE Trans. Magnetics, MAG-25, p. 3396 (1989)

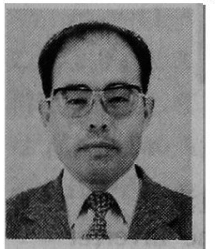

\section{園 田 敏 勝（正員）}

昭和 19 年 3 月 7 日生。 40 年 3 月 東京都立向島工業高等学校 (定) 電 気科卒業。 41 年 8 月東海大学短期 大学部 (二部) 電気工学科 2 年中 退。 41 年 8 月九州大学工学部技官, 46 年 4 月九州工 業大学工学部技官, 51 年 5 月九州工業大学助手, 現 在に至る。可変速ドライブシステムおよび検出器に関 する研究に従事。1990 年 IEEE/IAS 論文賞。日本非 破壊検查協会, 日本応用磁気学会, IEEE 会員。

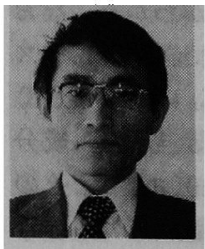

$$
\text { 上田隆三（正員） }
$$

昭和 15 年 12 月 15 日生。 45 年 3 月九州工業大学大学院工学研究科電 気工学専攻修士課程修了。 45 年 4 月同大学電子工学科助手, 49 年 4 月同第二部電気工学科講師, 50 年 7 月同助教授, 60 年 4 月同教授, 学部改組により電気工学科教授, 現在 に至る。工学博士, 電力系統の安定性, 誘導機駆動シ ステムの安定性, センサなどに関する研究に従事。 1990 年 IEEE/IAS 賞。日本非破壊検査協会, 日本応 用磁気学会, IEEE 会員。 